\title{
Laboratoryjna symulacja wgniatania ziaren podsadzki w formację złożową typu tight gas
}

\section{Laboratory simulation of proppant embedment into a tight gas formation}

\author{
Mateusz Masłowski \\ Instytut Nafty i Gazu - Państwowy Instytut Badawczy
}

\begin{abstract}
STRESZCZENIE: W artykule przedstawiono tematykę związaną z uszkodzeniem powierzchni ściany szczeliny po wykonanym zabiegu hydraulicznego szczelinowania. Spowodowane jest to wgniataniem się ziaren materiału podsadzkowego (ang. proppant) w ścianę szczeliny (ang. embedment) oraz wyciskiem materiału skalnego na powierzchni ściany szczeliny. Zjawiska te mają negatywny wpływ na przepływ węglowodorów ze skały do szczeliny oraz utrzymanie rozwartości szczeliny po zaciśnięciu się górotworu, gdy ciśnienie obniży się poniżej ciśnienia szczelinowania. Opracowaną metodykę obrazowania wielkości zjawiska wgniatania ziaren podsadzki w skałę i wycisku materiału skalnego zweryfikowano testami laboratoryjnymi. Badania wykonano na skale piaskowcowej czerwonego spągowca typu zamkniętego pochodzącej ze złoża niekonwencjonalnego. Charakteryzowała się ona zawartością kwarcu rzędu 73,3\%. Badano skałę wstępnie nasyconą płynem szczelinującym (sieciowany polimer naturalny). Do wypełnienia szczeliny użyto ceramicznego proppantu ISP 20/40 o granulacji ziaren od $0,850 \mathrm{~mm}$ do $0,425 \mathrm{~mm}$ i o koncentracji powierzchniowej rzędu 4,88 kg/m². Symulację zjawiska wgniatania ziaren podsadzki w skałę przeprowadzono przy naprężeniu ściskającym $86,5 \mathrm{MPa}$ i w temperaturze $127^{\circ} \mathrm{C}$. Na podstawie wykonanego obrazowania powierzchni czołowych rdzeni (ścian szczeliny) w wymiarze 3D oraz ich analiz uzyskano całkowitą głębokość wgnieceń podsadzki w ściany szczeliny - rzędu 0,091 mm oraz całkowitą wysokość wycisku materiału skalnego - rzędu $0,077 \mathrm{~mm}$. Całkowite zmniejszenie rozwartości szczeliny z podsadzką, z uwzględnieniem badanych zjawisk, było równe $0,168 \mathrm{~mm}$. Uszkodzenie ściany szczeliny przez ziarna podsadzki wynosiło 31,5\%. Zastosowana procedura badawcza może stanowić jedną z metod oceny podatności skały złożowej na zjawisko wgniatania ziaren proppantu w skałę oraz zjawisko wycisku materiału skalnego na powierzchni ściany szczeliny. Może być też przydatna w prawidłowym doborze technologii szczelinowania, płynu szczelinującego i podsadzki w zabiegach szczelinowania złóż węglowodorów.
\end{abstract}

Słowa kluczowe: wgniatanie podsadzki, hydrauliczne szczelinowanie, materiał podsadzkowy, płyn szczelinujący, złoża niekonwencjonalne.

\begin{abstract}
This paper presents the issue of damage to the fracture wall surface, after hydraulic fracturing of the hydrocarbons reservoir. It is caused by proppant embedment into the fracture wall and the impression of rock material from the fracture wall surface. These phenomena have a negative effect on the flow of hydrocarbons from the rock to the fracture and on maintaining the width of fracture after the closing of the rock mass, when the pressure drops below the fracturing pressure. The developed methodology for imagining the size of the embedment phenomenon and the rock material impression was verified by laboratory tests. The tests were performed for Rotliegend sandstone (tight gas formation) from Polish unconventional reservoirs. It was characterized by a quartz content of $73.3 \%$. The tests were conducted for an initially soaked rock (crosslinked natural polymer). The fracture was packed with proppant ceramics ISP 20/40 with grain size from $0.850 \mathrm{~mm}$ to $0.425 \mathrm{~mm}$ and the surface concentration of the proppant was $4.88 \mathrm{~kg} / \mathrm{m}^{2}$. The laboratory simulation of the embedment phenomenon was performed for compressive stress of $86.5 \mathrm{MPa}$ for 6 hours at $127^{\circ} \mathrm{C}$. Based on the imagining of the core faces (fracture walls) in 3D and their analyses, the total average depth of proppant embedment into the fracture walls was $0.091 \mathrm{~mm}$ and the total average height of the rock material squeezed out was $0.077 \mathrm{~mm}$. The total decrease of the fracture width packed with proppant grains was $0.168 \mathrm{~mm}$. The average damage of the fracture surface by the proppant grains was $31.5 \%$. The test procedure applied might be used in the evaluation of the susceptibility of reservoir rock to the embedment phenomenon and the rock material squeezed out, as well as for the selection of frac fluid and proppant for fracturing of hydrocarbon reservoirs.
\end{abstract}

Key words: proppant embedment, hydraulic fracturing, proppant, fracturing fluid, unconventional reservoirs.

Autor do korespondencji: M. Masłowski, e-mail: mateusz.maslowski@inig.pl

Artykuł nadesłano do Redakcji: 10.12.2019 r. Zatwierdzono do druku: 31.03.2020 r. 


\section{Wstęp}

W związku ze zmniejszającymi się zasobami węglowodorów w złożach konwencjonalnych coraz większą rolę w światowym i krajowym bilansie energetycznym odgrywają złoża niekonwencjonalne. Do złóż niekonwencjonalnych zalicza się: złoża typu zamkniętego (ang. tight gas), łupki gazonośne (ang. shale gas), pokłady węgla (ang. coalbed methane) oraz złoża hydratów (Paktinat et al., 2006; Poprawa i Kiersnowski, 2010; Kasza, 2011; Wójcicki et al., 2014). Charakteryzują się one bardzo małą przepuszczalnością oraz porowatością. Wykonane w ostatnim czasie prace geologiczno-poszukiwawcze wskazują na znaczny potencjał występowania w Polsce węglowodorów w piaskowcach typu zamkniętego (Papiernik et al., 2010; Poprawa i Kiersnowski, 2010; Wójcicki et al., 2014). Mogą one występować w tych samych skałach zbiornikowych co konwencjonalne złoża, jednakże na większych głębokościach i w pułapkach złożowych o gorszych parametrach zbiornikowych. Złoża te charakteryzują się niską przepuszczalnością (poniżej $0,1 \mathrm{mD})$, powodującą bardzo niskie tempo przepływu węglowodorów do odwiertu, a także jego szybki spadek w czasie eksploatacji, związany zazwyczaj z drobnoziarnistym charakterem skały zbiornikowej, jej kompakcją oraz cementacją. Na podstawie wykonanych analiz parametrów skał zbiornikowych typu zwięzłych piaskowców (Papiernik et al., 2010; Poprawa i Kiersnowski, 2010; Wójcicki et al., 2014) zostały wytypowane obszary perspektywiczne. Dokładne badania przeprowadzono głównie w przypadku piaskowców: basenu kambryjskiego na kratonie wschodnioeuropejskim, basenu dewonu dolnego (głównie południowa i wschodnia Polska), basenów karbonu dolnego (monoklina przedsudecka) i górnego (Pomorze Zachodnie i region lubelski), polskiego basenu czerwonego spągowca (perm), basenu górnośląskiego (karbon górny). Najbardziej perspektywiczne obszary występowania węglowodorów według Wójcickiego et al. (2014) i Dyrki et al. przedstawiono na rysunku 1.

Eksploatacja złóż niekonwencjonalnych związana jest z zastosowaniem nowych technik i technologii poszukiwawczych oraz nowych metod stymulacji wydobycia węglowodorów (Reinicke et al., 2010; Terracina et al., 2010; Czupski et al., 2013; Masłowski, 2014; Kasza, 2019). Mają one za zadanie umożliwić wydobycie węglowodorów z największej części złoża. Eksploatacja odbywa się zarówno przez odwierty pionowe, jak i horyzontalne (poziome). Hydrauliczne szczelinowanie z materiałem podsadzkowym jest jedną z metod stymulacji niekonwencjonalnych złóż węglowodorów, umożliwiającą zwiększenie powierzchni kontaktu odwiertu ze złożem. Odbywa się to poprzez połączenie odwiertu przez wypełnione podsadzką szczeliny z bardziej odległymi partiami złoża (Economides i Nolte, 1989; Gidley et al., 1989; Kasza, 2011; Masłowski, 2014; Zhang et al., 2017). Zabiegi szczelinowania niekonwencjonalnych piaskowców są podobne do zabiegów wykonywanych na złożach konwencjonalnych (Reinicke et al., 2006; Guo i Liu, 2012). Różnią się one jedynie większą ilością zatłaczanego płynu szczelinującego, podsadzką oraz bardziej rozbudowanym systemem szczelin, przedstawionym na rysunku 2.

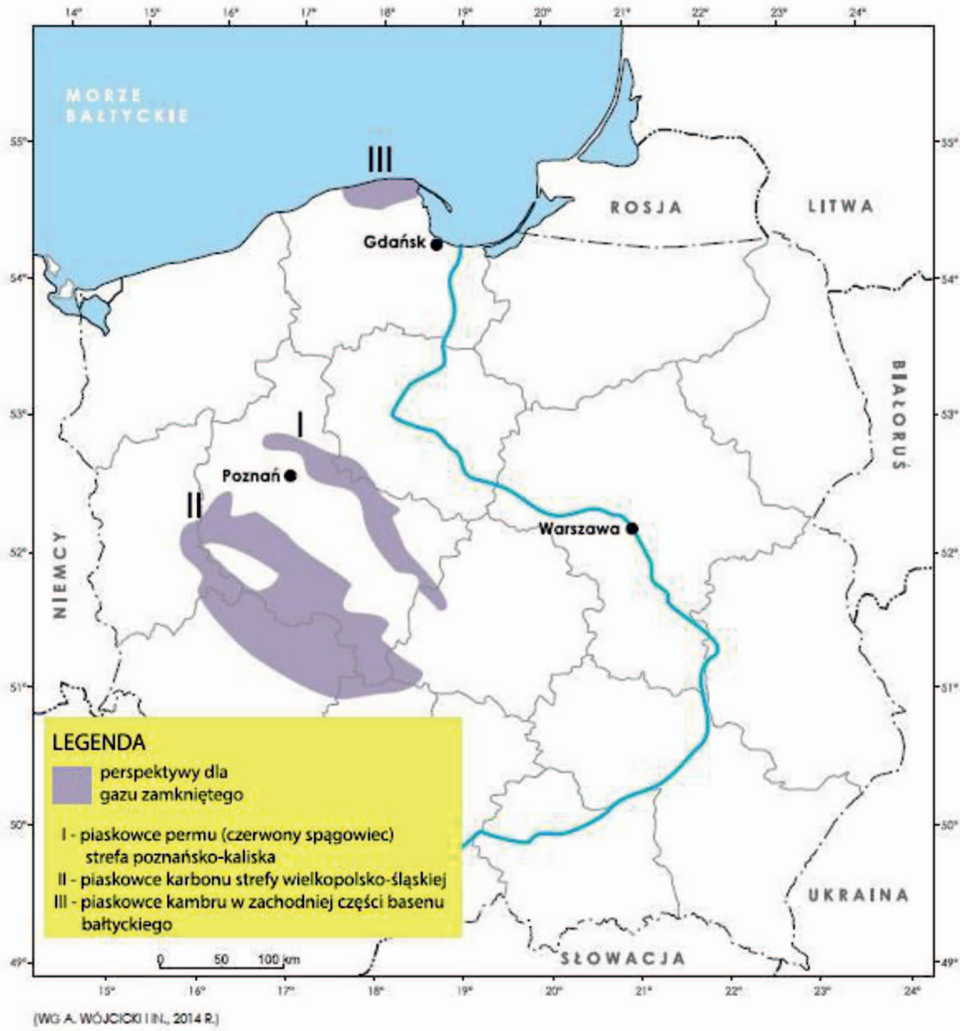

Rys. 1. Perspektywy występowania piaskowca typu zamkniętego (tight gas) w Polsce (Wójcicki et al., 2014; Dyrka et al.)

Fig. 1. Prospects for occurrence of tight gas sandstone in Poland (Wójcicki et al., 2014; Dyrka et al.)

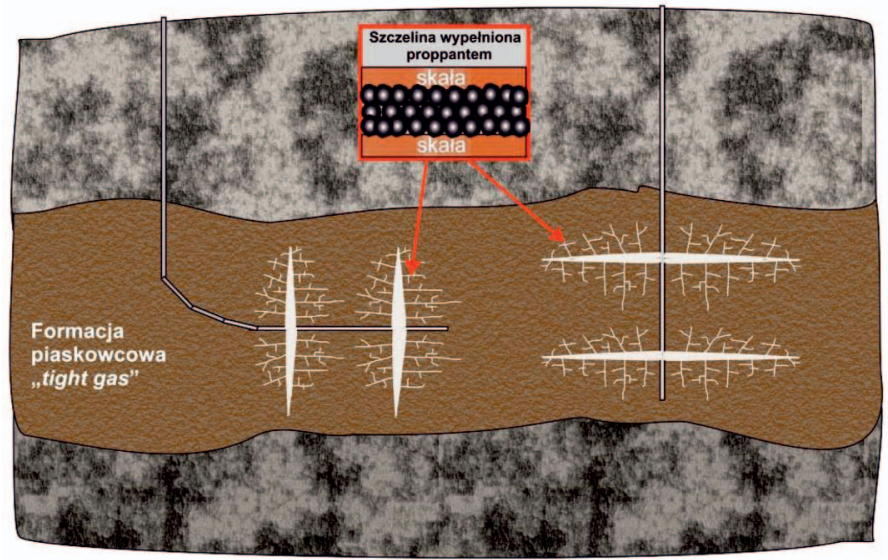

Rys. 2. Schemat hydraulicznego szczelinowania w niekonwencjonalnych złożach węglowodorów

Fig. 2. Hydraulic fracturing pattern in unconventional reservoirs 
Powstałe podczas zabiegu szczeliny i spękania w skale wypełnia się podsadzką. Zapobiega to całkowitemu zamknięciu się szczeliny (Economides i Nolte, 1989; Terracina et al., 2010; Masłowski, 2014; Masłowski et al., 2018b, 2019). Dzięki temu uzyskuje się przepływ węglowodorów ze złoża do odwiertu. Technologia wykonania zabiegu hydraulicznego szczelinowania niekonwencjonalnej skały piaskowcowej oraz zasięg powstałych i podsadzonych proppantem szczelin zależy od wielu czynników. Należą do nich między innymi (Economides i Nolte, 1989): właściwości skały złożowej oraz warstw ją okalających, miąższość złoża, temperatura i ciśnienie złożowe, medium eksploatowane oraz wielkość uzyskanego kontaktu złoża z odwiertem. Wybór rodzaju płynu szczelinującego i proppantu jest jednym z ważniejszych punktów w procesie udostępniania formacji złożowej (Economides i Nolte, 1989; Czupski et al., 2013; Masłowski et al., 2018b, 2019). Do zabiegów hydraulicznego szczelinowania skał piaskowcowych typu zamkniętego stosuje się technologie polimerów liniowych, sieciowanych polimerów liniowych lub tzw. zabiegi hybrydowe. Płyny charakteryzują się własnościami reologicznymi zbliżonymi do własności płynów stosowanych w zabiegach hydraulicznego szczelinowania złóż konwencjonalnych. W przypadku występowania wysokich temperatur złożowych często wykorzystuje się sieciowane polimery naturalne. W niższych temperaturach stosuje się zabiegi hybrydowe, wykorzystujące dwa różne płyny szczelinujące. Płyn o niskiej lepkości (technologia polimerów liniowych) jest używany do inicjacji i propagacji szczeliny. Po nim wtłacza się płyn na bazie sieciowanego polimeru o niskiej koncentracji polimeru, który służy do zwiększania rozwartości szczeliny i transportu podsadzki. Płyny wtłacza się naprzemiennie w wieloetapowym procesie szczelinowania piaskowców typu tight gas. W każdym zabiegu szczelinowania konieczne jest dodawanie do płynów szczelinujących materiałów chemicznych (tzw. łamaczy) powodujących degradację polimeru. Dodawanie ich zaleca się bez względu na stosowane płyny zabiegowe oraz temperaturę złożową. Właściwy dobór ilości łamacza powinien być odpowiednio zaprojektowany, jako funkcja temperatury złożowej i przewidywanego czasu trwania zabiegu.

Przed doborem właściwej technologii szczelinowania niekonwencjonalnej skały piaskowcowej ważne jest zbadanie oraz ograniczenie wielkości występowania zjawisk niekorzystnie wpływających na przepływ uwolnionych węglowodorów ze skały do szczeliny i kolejno do odwiertu. Należy zaznaczyć, że oprócz sposobu transportu i umieszczania podsadzki w szczelinie podczas zabiegu hydraulicznego szczelinowania - na wielkość efektywnego jej podsadzenia wpływa (Economides i Nolte, 1989; Reinicke et al., 2006, 2010; Czupski et al., 2013; Masłowski et al., 2018b, 2019): filtracja płynu szczelinującego w skałę złożową, niedokładne oczyszczenie szczeliny z polimerów po zabiegu, wgniatanie się ziaren podsadzki w ścianę szczeliny (ang. embedment), kruszenie, pękanie ziaren materiału podsadzkowego, reorientacja ziaren podsadzki, wymywanie się ziaren ze szczeliny, sedymentacja osadów podczas zabiegu oraz eksploatacji złoża.

\section{Zjawisko wgniatania ziaren podsadzki w skałę złożową (embedment)}

W obrębie ściany szczeliny oprócz zjawiska filtracji płynu szczelinującego ma miejsce zjawisko wgniatania się ziaren podsadzki w skałę złożową (Reinicke et al., 2006, 2010; Masłowski, 2015; Masłowski i Biały, 2016; Masłowski et al., 2016, 2018a, 2018b, 2019). Zjawisko to występuje po wykonanym zabiegu hydraulicznego szczelinowania i zaciśnięciu się górotworu. Wpływ uszkodzenia powierzchni ściany szczeliny przez ziarna podsadzki na spadek rozwartości szczeliny przedstawiono na rysunku 3.

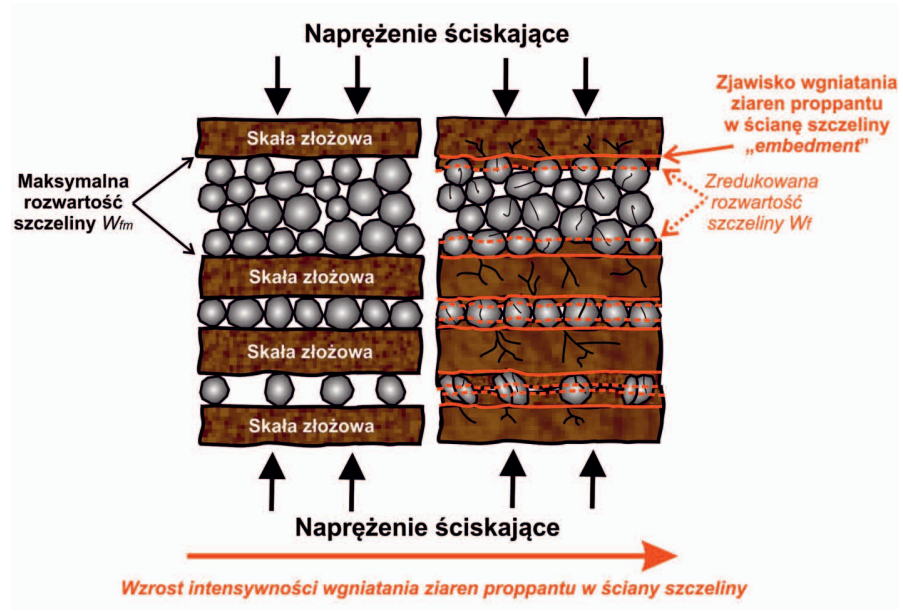

Rys. 3. Zobrazowanie wpływu zjawiska wgniatania ziaren podsadzki w skałę na wielkość uszkodzenia ściany szczeliny i rozwartości szczeliny z podsadzką o różnej koncentracji powierzchniowej

Fig. 3. Visualization of the effect of embedment phenomenon on the fracture wall damage and the width of the pack fracture with proppant, for various proppant surface concentration.

Uszkodzenie ściany szczeliny związane jest z kruszeniem się ziaren skały złożowej, a tym samym powoduje wzrost zagęszczania się jej okruchów w przestrzeni porowej. Zjawisko to niekorzystnie wpływa na przepływ węglowodorów ze skały do szczeliny podsadzonej podsadzką. Z kolei spadek rozwartości szczeliny ogranicza przepływ węglowodorów do odwiertu. $\mathrm{Na}$ wielkość zjawiska embedment wpływa między innymi: rodzaj skały złożowej, własności geomechaniczne skały złożowej, technologia zabiegu szczelinowania, rodzaj podsadzki oraz wielkości naprężeń ściskających i temperatury. Od wielu lat podejmuje się szereg badań laboratoryjnych oraz prób matematycznego 
obrazowania/modelowania zjawiska wgniatania ziaren podsadzki w skałę złożową / ścianę szczeliny (Reinicke et al., 2006, 2010; Terracina et al., 2010; Akrad et al., 2011; Alramahi i Sundberg, 2012; Ghassemi i Suarez-Rivera, 2012a, 2012b; Guo i Liu, 2012; Masłowski, 2015; Masłowski i Biały, 2016; Masłowski et al., 2016, 2018a, 2018b, 2019; Zhang et al., 2017). Polegają one na określeniu wpływu zjawiska wgniatania ziaren podsadzki w skałę na efektywne podsadzenie wytworzonej w skale złożowej szczeliny. Najczęściej dotyczą one badań skały ilasto-mułowcowej (shale gas). Wraz z poszerzającymi się możliwościami sprzętowymi oraz oprogramowania komputerowego są one unowocześniane, a tym samym pozwalają na lepsze odwzorowanie tego niekorzystnego zjawiska.

\section{Metodyka obrazowania wielkości zjawiska wgniatania ziaren podsadzki dla skały piaskowcowej typu zamkniętego}

W celu prawidłowego wykonania laboratoryjnej symulacji zjawiska wgniatania ziaren podsadzki w skałę wymagane jest między innymi zebranie informacji odnośnie do: rodzaju skały złożowej, warunków złożowych, technologii wykonania zabiegu hydraulicznego szczelinowania złoża. Ważne są również: właściwe przygotowanie próbek skały, wyznaczenie pierwotnej chropowatości ściany szczeliny, głębokości i szerokości wgnieceń ziaren podsadzki w ścianę szczeliny, wysokości wycisku materiału skalnego z powierzchni ściany szczeliny oraz właściwa analiza uzyskanych wyników.

Średnią pierwotną chropowatość powierzchni czołowych cylindrycznych rdzeni (ściany szczeliny) określa się według równania (1) wzdłuż danego odcinka pomiarowego przedstawionego na rysunku 4 (Masłowski, 2015; Masłowski i Biały, 2016; Masłowski et al., 2016, 2018a, 2018b, 2019).

$$
R_{a}=\frac{\sum_{i=1}^{n_{v}} H_{v_{i}}+\sum_{i=1}^{n_{p}} H_{p_{i}}}{n_{v}+n_{p}}
$$

gdzie:

$R_{a}$ - średnia chropowatość profilu powierzchni wzdłuż odcinka pomiarowego [mm],

$H_{v}$ - głębokość doliny [mm],

$H_{p}-$ wysokość szczytu [mm],

$n_{v}$ - liczba wszystkich dolin [-],

$n_{p}-$ liczba wszystkich szczytów [-].

Następnie, po wykonaniu laboratoryjnej symulacji wgniatania ziaren podsadzki w skałę, określa się wielkości charakteryzujące to zjawisko. Średnią głębokość wgnieceń wyznacza się według równania (2), średnią wysokość wycisku materiału skalnego - według równania (3), średnie uszkodzenie ściany

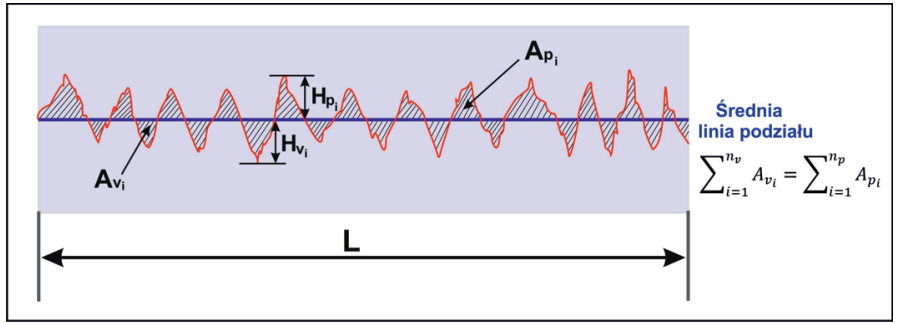

Rys. 4. Przykładowy profil chropowatości powierzchni wzdłuż odcinka pomiarowego dla wytypowanego obszaru na powierzchni ściany szczeliny

Fig. 4. An example of the surface roughness profile along the measurement section for the selected area on the surface of the fracture face

szczeliny przez wgniecenia ziaren podsadzki - według równania (4). Przedstawione wielkości określa się z profili głębokości i wycisków wzdłuż kilku odcinków pomiarowych (rys. 5) dla wytypowanych obszarów na powierzchni czołowej rdzenia (ściany szczeliny) (Masłowski, 2015; Masłowski i Biały, 2016; Masłowski et al., 2016, 2018a, 2018b, 2019).

$$
H_{e}=\frac{\sum_{i=1}^{n_{e}} H_{e_{i}}}{n_{e}}
$$

gdzie:

$H_{e}$ - średnia głębokość wgniatania się ziaren podsadzki w pierwotną powierzchnię ściany szczeliny (skałę) dla profilu, wzdłuż odcinka pomiarowego [mm],

$H_{e_{i}}$ - indywidualna głębokość wgniecenia ziarna podsadzki w pierwotną powierzchnię ściany szczeliny [mm],

$n_{e}-$ liczba wszystkich wgnieceń ziaren podsadzki w powierzchnię ściany szczeliny [-].

$$
H_{w}=\frac{\sum_{i=1}^{n_{w}} H_{w_{i}}}{n_{w}}
$$

gdzie:

$H_{w}$ - średnia wysokość wycisku materiału skalnego (pochodzącego z wgniecenia ziarna podsadzki w skałę) na pierwotnej powierzchni ściany szczeliny dla profilu, wzdłuż odcinka pomiarowego [mm],

$H_{w_{i}}$ - indywidualna wysokość wycisku materiału skalnego z wgniecenia ziarna podsadzki w skałę na pierwotnej powierzchni ściany szczeliny [mm],

$n_{w}$ - liczba wszystkich wycisków materiału skalnego z wgniecenia ziarna podsadzki w skałę na powierzchni ściany szczeliny $[-]$.

$$
U S_{e}=\frac{\sum_{i=1}^{n_{e}} W_{e_{i}}}{L} \cdot 100
$$


gdzie:

$U S_{e}$ - średnie uszkodzenie ściany szczeliny (pochodzące z wgnieceń ziaren podsadzki w skałę) na pierwotnej powierzchni ściany szczeliny dla profilu, wzdłuż odcinka pomiarowego [\%],

$W_{e_{i}}-$ indywidualna szerokość wgniecenia ziarna podsadzki w pierwotną powierzchnię ściany szczeliny (szerokość doliny) [mm],

$L$ - długość odcinka pomiarowego [mm].

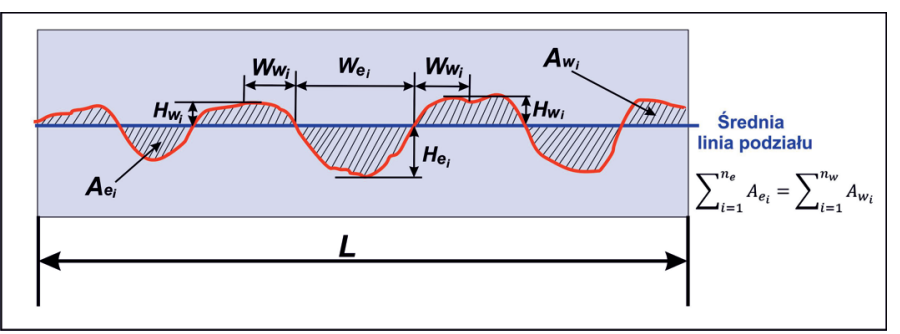

Rys. 5. Przykładowy profil głębokości i szerokości wgnieceń ziaren podsadzki oraz wysokości i szerokości wycisku materiału skalnego wzdłuż odcinka pomiarowego dla wytypowanego obszaru na powierzchni ściany szczeliny

Fig. 5. Sample profile of the depth and width of grain embedment and the height and width of the rock material squeezed out of along the measurement section in the selected area, on the surface of the fracture face

Całkowitą średnią głębokość $H_{e_{c}}$ wgnieceń ziaren podsadzki w ściany szczeliny, wyrażoną w milimetrach, określa się według równania (5).

$$
H_{e_{c}}=H_{e . G_{s r}}+H_{e . D_{s r}}
$$

gdzie:

$H_{e . G_{s r}}$ - średnia głębokość wgnieceń ziaren podsadzki w górną ścianę szczeliny [mm],

$H_{e . D_{s r}}$ - średnia głębokość wgnieceń ziaren podsadzki w dol-

ną ścianę szczeliny [mm]

są średnią arytmetyczną uzyskanych ich wartości z profili dla wytypowanych obszarów.

Całkowitą średnią wysokość $H_{w_{c}}$ wycisku materiału skalnego z wgnieceń ziaren podsadzki w skałę na powierzchni ściany szczeliny, wyrażoną w milimetrach, określa się według równania (6).

$$
H_{w_{c}}=H_{w \cdot G_{s r}}+H_{w \cdot D_{s r}}
$$

gdzie:

$H_{w . G_{s r}}$ - średnia wysokość wycisku materiału skalnego

z wgnieceń ziaren podsadzki dla górnej ściany szczeli-

ny $[\mathrm{mm}]$,

$H_{w . D_{s r}}$ - średnia wysokość wycisku materiału skalnego

z wgnieceń ziaren podsadzki dla dolnej ściany szczeli-

ny $[\mathrm{mm}]$

są średnią arytmetyczną uzyskanych ich wartości z profili dla wytypowanych obszarów.
Całkowite średnie uszkodzenie $U S_{e_{c}}$ ścian szczeliny (wgniecenia ziaren podsadzki w ścianę szczeliny) określa się według równania (7).

$$
U S_{e_{c}}=\frac{U S_{e . G_{s r}}+U S_{e . D_{s r}}}{2}
$$

gdzie:

$U S_{e . G_{s r}}$ - średnie uszkodzenie górnej ściany szczeliny

(wgniecenia ziaren podsadzki na powierzchni ściany

szczeliny) [\%],

$U S_{e . D_{s r}}$ - średnie uszkodzenie dolnej ściany szczeliny

(wgniecenia ziaren podsadzki na powierzchni ściany

szczeliny) [\%]

są średnią arytmetyczną uzyskanych ich wartości z profili dla wytypowanych obszarów.

Całkowity spadek rozwartości szczeliny $S W F_{c}$ wypełnionej podsadzką, związany ze zjawiskiem wgniatania ziaren podsadzki w skałę oraz wyciskiem materiału skalnego, wyrażony w milimetrach, określa się według równania (8).

$$
S W F_{c}=H_{e_{c}}+H_{w_{c}}
$$

\section{Charakterystyka skały złożowej, płynu szczelinującego oraz podsadzki}

Do badań użyto piaskowca czerwonego spągowca (perm) typu tight gas ze strefy poznańsko-kaliskiej (rys. 6a). Jest to piaskowiec eoliczny, charakterystyczny dla basenu permskiego. Skała ta jest również reprezentatywna dla permu dolnego i środkowego w obrębie czerwonego spągowca piętra autunu i saksonu. Wybrany piaskowiec charakteryzował się znaczącą ilością kwarcu $-73,3 \%$. Zawartość minerałów ilastych (miki) wynosiła 6,5\%, węglanów (dolomitu) 3,8\%, plagioklazów 4,4\%, skalenia potasowego $8,4 \%$, anhydrytu $1,4 \%$ oraz hematytu $2,2 \%$. Średnia głębokość występowania skały piaskowcowej czerwonego spągowca jest rzędu 3500-5000 m (Wójcicki et al., 2014). Na tej głębokości występują wysokie naprężenia ściskające, rzędu 71,2-101,8 MPa, oraz wysokie temperatury złożowe, rzędu $105-150^{\circ} \mathrm{C}$. Do nasycania skały został użyty płyn szczelinujący na bazie wody wodociągowej, oznaczony jako sieciowany polimer naturalny 40\# (rys. 6b). Posiadał on w swoim składzie: biocyd, środek żelujący (polimer naturalny o koncentracji $4,8 \mathrm{~kg} / \mathrm{m}^{3}$ ), sieciownik (związek borowy), łamacz (utleniacz), stabilizator minerałów ilastych oraz nanoemulsję. Do podsadzenia zasymulowanej szczeliny został użyty ceramiczny materiał podsadzkowy ISP 20/40 (rys. 6c) o rozmiarze ziaren rzędu $0,850-0,425 \mathrm{~mm}$. Średnia średnica ziaren proppantu $d_{a v}$ była rzędu $0,673 \mathrm{~mm}$. 

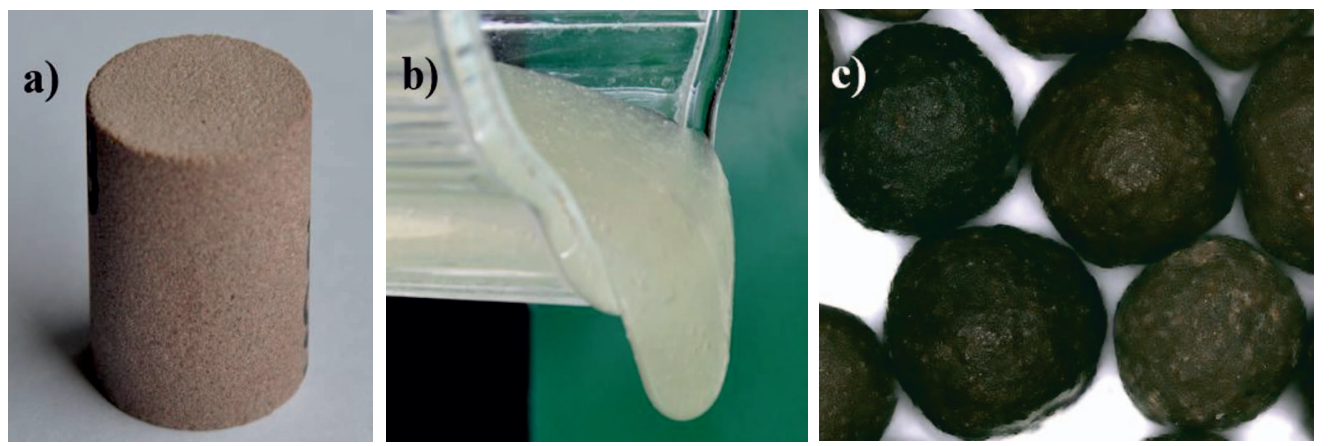

Rys. 6. a) Skała piaskowcowa czerwonego spągowca typu zamkniętego tight gas; b) sieciowany polimer naturalny 40\#; c) podsadzka ceramiczna ISP 20/40

Fig. 6. a) Rotliegend sandstone (tight gas); b) Crosslinked natural polymer; c) Proppant ceramic ISP 20/40

\section{Laboratoryjne symulowanie zjawiska wgniatania ziaren podsadzki w skałę oraz analiza otrzymanych wyników}

Badania wykonano dla cylindrycznych rdzeni skalnych o średnicy 2,54 cm i długości około $1 \mathrm{~cm}$. Laboratoryjna symulacja zjawiska wgniatania ziaren podsadzki w skałę polegała na umieszczeniu ziaren pomiędzy dolną powierzchnią czołową górnego rdzenia a górną powierzchnią dolnego rdzenia (rys. 7a)
Do symulacji przyjęto średnią głębokość występowania piaskowca z czerwonego spągowca rzędu $4250 \mathrm{~m}$ oraz temperaturę $127^{\circ} \mathrm{C}$ i naprężenie $86,5 \mathrm{MPa}$. Rdzenie skalne były wstępnie nasycane płynem szczelinującym przez 2 godziny w temperaturze $127^{\circ} \mathrm{C}$ i pod ciśnieniem 6,9 MPa. Warunki wykonania laboratoryjnej symulacji zjawiska wgniatania ziaren podsadzki w skałę przedstawiono w tabeli 1 .

Wygląd powierzchni czołowej rdzenia, obrazującej ścianę szczeliny, zaprezentowano na rysunku 9. Wielkości a)
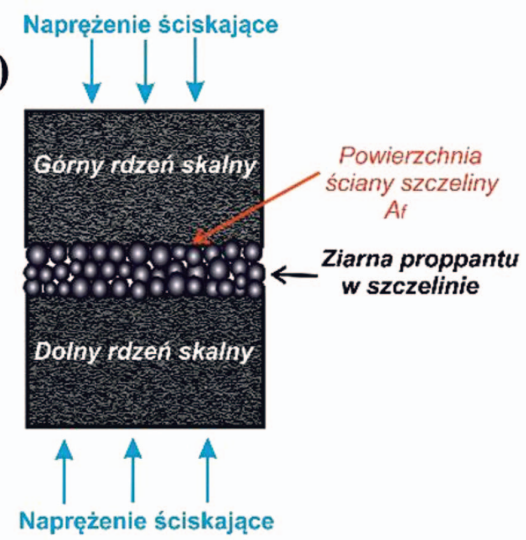
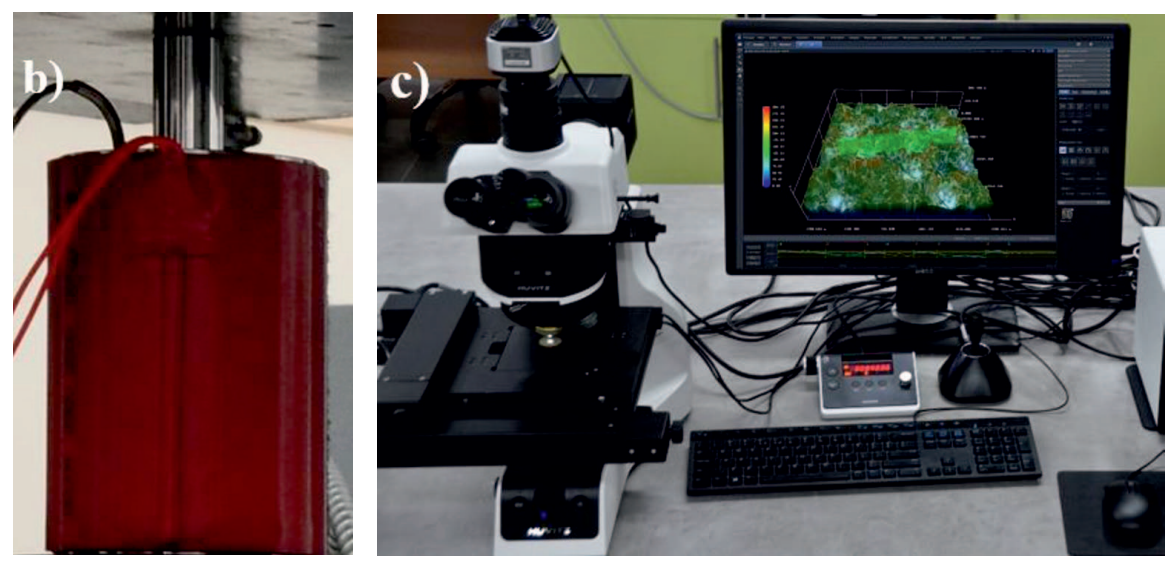

Rys. 7. a) Schemat umieszczenia podsadzki i rdzeni; b) prasa hydrauliczna wraz z komorą embedment; c) mikroskop optyczny wraz z cyfrowym oprzyrządowaniem i oprogramowaniem 3D

Fig. 7. a) Setting of cores and proppant into the chamber; b) Hydraulic press and embedment chamber; c) Optical microscope with 3D software

w komorze do symulacji zjawiska embedment (rys. 7b). Komorę umieszczono w prasie hydraulicznej i po osiągnięciu zadanej temperatury badania podsadzkę poddawano oddziaływaniu zadanego naprężenia ściskającego przez zadany czas. Następnie rozkręcono komorę i wykonano analizę powierzchni czołowej rdzenia (ściany szczeliny) pod mikroskopem optycznym (rys. 7c) według procedury opisanej we wcześniejszej części artykułu. Analizę powierzchni czołowej każdego z rdzeni wykonano dla pięciu wytypowanych obszarów, przedstawionych na rysunku 8 .

Średnia pierwotna chropowatość $R_{a}$ dolnej powierzchni czołowej górnego rdzenia wyniosła $0,0162 \mathrm{~mm}$, natomiast górnej powierzchni czołowej dolnego rdzenia $-0,0143 \mathrm{~mm}$.

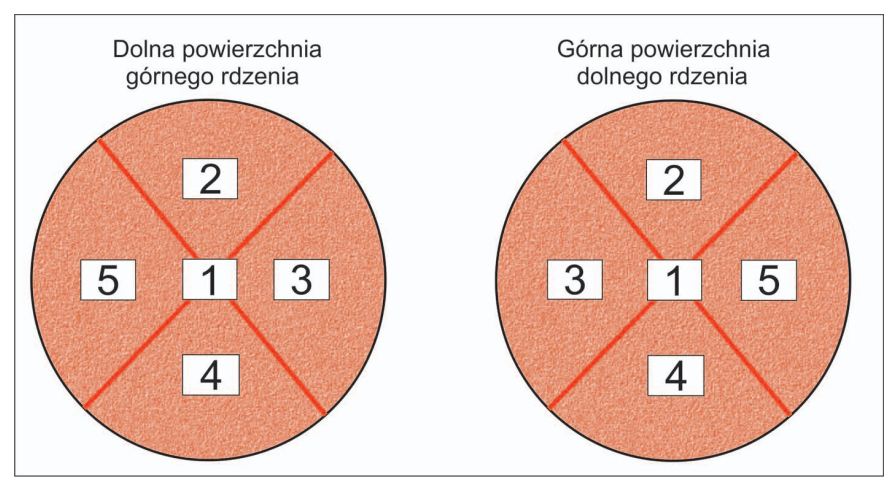

Rys. 8. Rozmieszczenie obszarów do analizy powierzchni czołowych rdzeni

Fig. 8. Placement of areas for core surface analysis 
Tabela 1. Warunki wykonania testu

Table 1. Test conditions

\begin{tabular}{|l|c|}
\hline Temperatura $\left[{ }^{\circ} \mathrm{C}\right]$ & 127,0 \\
\hline Koncentracja powierzchniowa podsadzki $\left[\mathrm{kg} / \mathrm{m}^{2}\right]$ & 4,88 \\
\hline Zadane naprężenie ściskające $[\mathrm{MPa}]$ & 86,5 \\
\hline Czas działania zadanego naprężenia ściskającego [godziny] & 6 \\
\hline
\end{tabular}

charakteryzujące zjawisko wgniatania ziaren podsadzki w skałę i wycisku materiału skalnego zostały przedstawione na rysunku 11 oraz w tabeli 2. Przykładowe obrazowanie powierzchni czołowej rdzenia wraz z określeniem wielkości charakteryzujących zjawisko embedment dla jednego z analizowanych obszarów pokazano na rysunku 9.
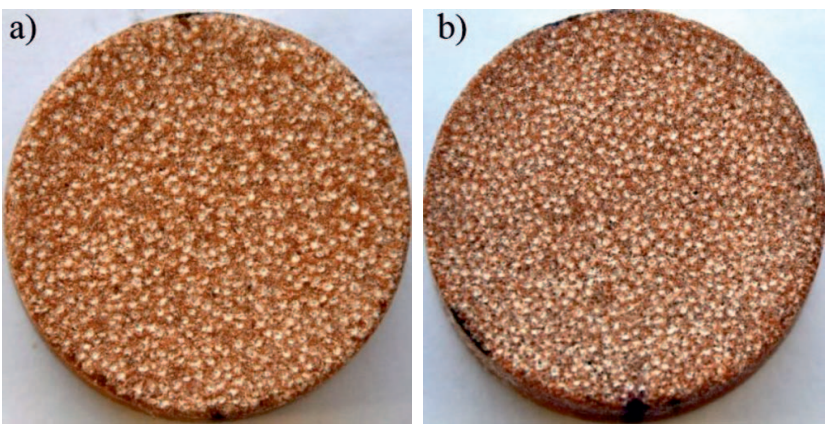

Rys. 9. Wygląd powierzchni czołowej: a) górnego rdzenia i b) dolnego rdzenia - po laboratoryjnej symulacji zjawiska embedment

Fig. 9. Surface: a) top core and b) bottom core, after laboratory simulation of embedment
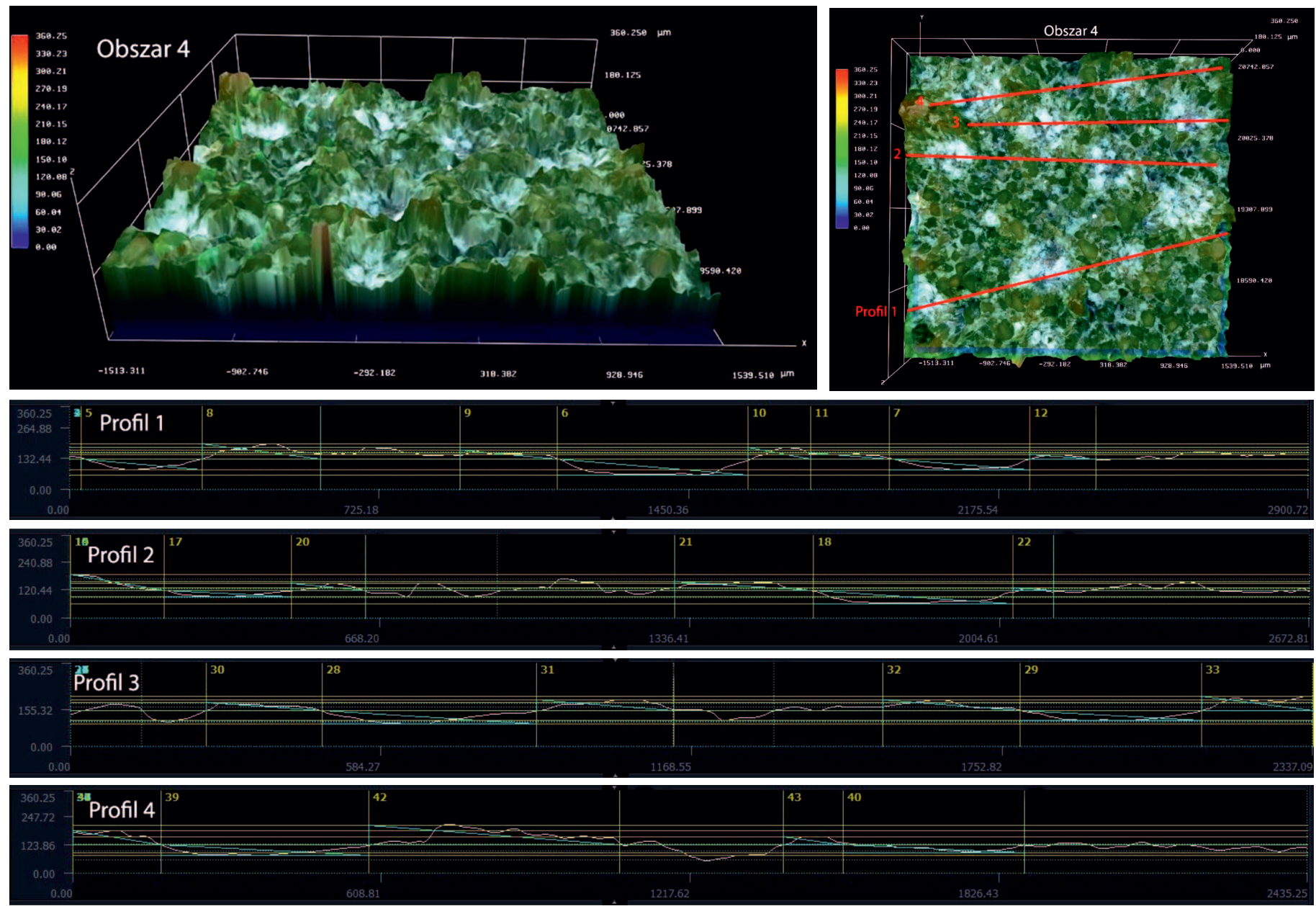

Rys. 10. Określenie średniej głębokości wgnieceń ziaren podsadzki $\left(H_{e}=0,048 \mathrm{~mm}\right)$ i wycisku materiału skalnego $\left(H_{w}=0,045 \mathrm{~mm}\right)$ oraz średnie uszkodzenie ściany szczeliny $(31,6 \%)$ dla jednego z obszarów wytypowanych na dolnej powierzchni czołowej górnego rdzenia

Fig. 10. Determination of the average depth of grains embedment $\left(H_{e}=0,048 \mathrm{~mm}\right)$ and the average height of the rock material squeezed out $\left(H_{w}=0.045 \mathrm{~mm}\right)$ and the average damage of the fracture wall $(31.6 \%)$ for one area on the top core

\section{Podsumowanie i wnioski}

W artykule zobrazowano i określono wielkości opisujące zjawisko wgniatania ziaren podsadzki w ściany szczeliny (embedment) oraz zjawisko wycisku materiału skalnego z powierzchni ściany szczeliny. Badanie wykonano na wstępnie nasyconej płynem szczelinującym skale piaskowcowej czerwonego spągowca typu zamkniętego, pochodzącej z polskiego złoża niekonwencjonalnego, ze strefy poznańsko-kaliskiej. Charakteryzowała się ona dużą zawartością kwarcu, rzędu 73,3\%. Jako płyn szczelinujący użyto sieciowanego polimeru naturalnego. Do podsadzenia szczeliny została 
Tabela 2. Wyniki analizy wielkości zjawiska embedment dla górnej i dolnej ściany szczeliny

Table 2. Results of the analysis of the embedment phenomenon parameters for the top and bottom of the fracture wall

\begin{tabular}{|l|c|c|c|}
\hline \multicolumn{1}{|c|}{ Wielkości zjawiska embedment } & $\begin{array}{c}\text { Dolna powierzchnia } \\
\text { czolowa górnego rdzenia }\end{array}$ & $\begin{array}{c}\text { Górna powierzchnia } \\
\text { czołowa dolnego rdzenia }\end{array}$ & \begin{tabular}{c} 
Szczelina \\
\hline Liczba badanych obszarów $[-]$
\end{tabular} \\
\hline Całkowite pole powierzchni obszarów $\left[\mathrm{mm}^{2}\right]$ & 5 & 5 & 10 \\
\hline Całkowita długość odcinków pomiarowych, $L_{c}[\mathrm{~mm}]$ & 51,915 & 40,992 & 82,907 \\
\hline Średnia głębokość wgnieceń ziaren podsadzki, $H_{e_{s r}}[\mathrm{~mm}]$ & $0,052 \pm 0,005$ & 52,376 & 104,566 \\
\hline Średnia wysokość wycisku materiału skalnego, $H_{w_{s r}}[\mathrm{~mm}]$ & $0,043 \pm 0,004$ & $0,038 \pm 0,005$ & $0,091 \pm 0,010$ \\
\hline Uszkodzenie ściany szczeliny, $U S_{e}[\%]$ & $33,6 \pm 1,7$ & $0,034 \pm 0,004$ & $0,077 \pm 0,008$ \\
\hline
\end{tabular}

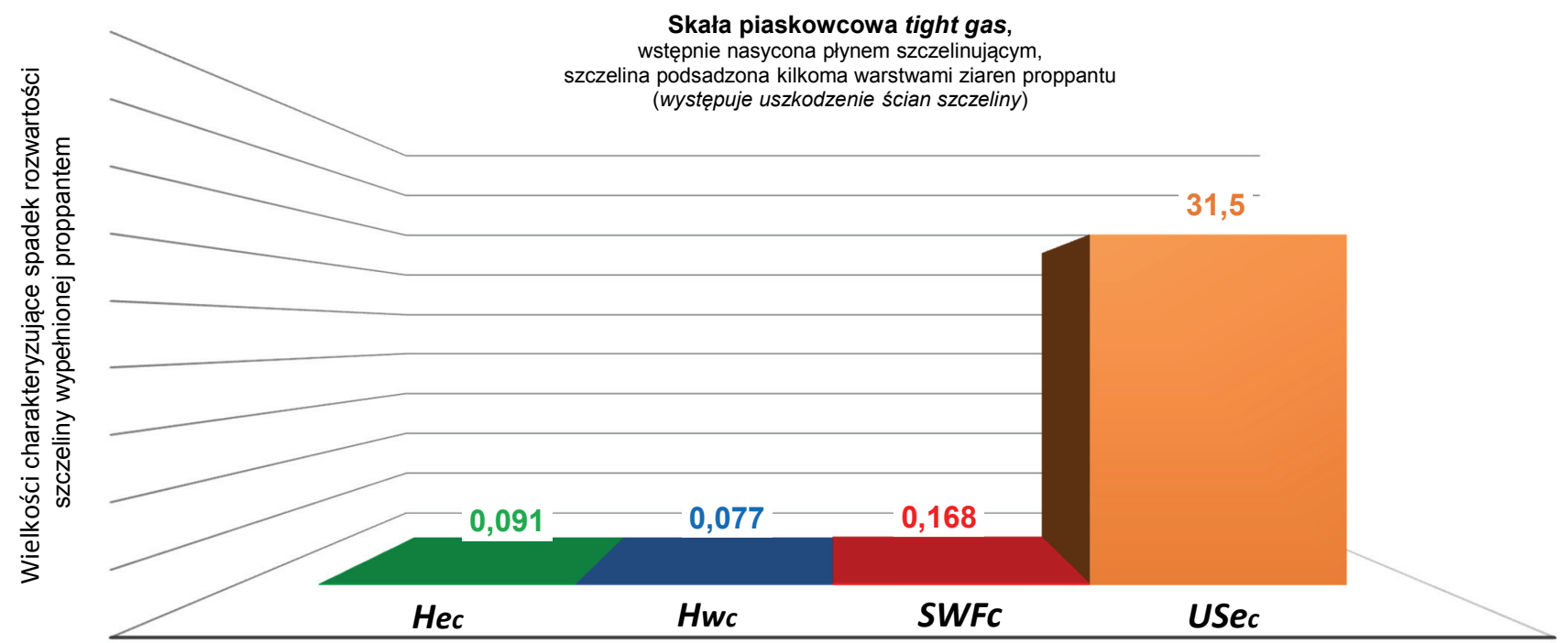

- Hec - Całkowita głębokość wgnieceń ziaren proppantu w ściany szczeliny [mm]

- Hwc - Całkowita wysokość wycisku materiału skalnego na powierzchniach ścian szczeliny [mm]

n SWFc - Całkowity spadek rozwartości szczeliny wypełnionej proppantem, z uwzględnieniem zjawiska embedmentu i wycisku materiału skalnego [mm]

- USec - Całkowite średnie uszkodzenie ścian szczeliny przez wgniecenia ziaren proppantu w skałę, dla szczeliny [\%]

Rys. 11. Wielkości spadku rozwartości szczeliny wypełnionej podsadzką o koncentracji powierzchniowej $4,88 \mathrm{~kg} / \mathrm{m}^{2} \mathrm{dla}$ skały piaskowcowej czerwonego spągowca w temperaturze $127^{\circ} \mathrm{C}$ i przy naprężeniu ściskającym $86,5 \mathrm{MPa}$

Fig. 11. Parameters of reduction of the fracture width packed with proppant at surface concentration of proppant equal to $4.88 \mathrm{~kg} / \mathrm{m}^{2}$, for Rotliegend sandstone (tight gas), at the temperature of $127^{\circ} \mathrm{C}$ and axial compression stress of $86.5 \mathrm{MPa}$

wykorzystana ceramiczna podsadzka ISP 20/40 o średnicy ziaren od $0,850 \mathrm{~mm}$ do $0,425 \mathrm{~mm}$ i o koncentracji powierzchniowej $4,88 \mathrm{~kg} / \mathrm{m}^{2}$. Symulację zjawiska embedment wykonano w warunkach oddziaływania naprężenia ściskającego podsadzkę wynoszącego 86,5 MPa przez okres 6 godzin w temperaturze $127^{\circ} \mathrm{C}$. Na podstawie wykonanego obrazowania powierzchni czołowych rdzeni (ścian szczeliny) w wymiarze 3D oraz ich analiz uzyskano:

- całkowitą głębokość wgnieceń ziaren podsadzki w ściany szczeliny - rzędu 0,091 mm;

- całkowitą wysokość wycisku materiału skalnego - rzędu $0,077 \mathrm{~mm}$;

- całkowity spadek rozwartości szczeliny z podsadzką z uwzględnieniem badanych niekorzystnych zjawisk równy $0,168 \mathrm{~mm}$;
- uszkodzenie ściany szczeliny przez ziarna podsadzki - równe $31,5 \%$.

Otrzymane wyniki badań potwierdzają, że w zabiegach hydraulicznego szczelinowania formacji złożowej występuje niekorzystne zjawisko wgniatania ziaren podsadzki w skałę. Zaobserwowano również zniekształcenie ścian szczeliny na skutek tego zjawiska. Zostało to przedstawione na rysunkach 9 i 10. Laboratoryjna symulacja zjawiska wgniatania ziaren podsadzki może stanowić jedną z metod oceny podatności skały na zmniejszenie rozwartości wytworzonej szczeliny. Wyniki tych badań mogą służyć jako wstępna ocena efektywności podsadzenia szczeliny w zabiegach hydraulicznego szczelinowania na etapie ich projektowania.

W przypadku symulowania rozwartości szczeliny podsadzonej tylko jedną warstwą podsadzki - za maksymalną możliwą 
do uzyskania rozwartość szczeliny bez występowania zjawiska embedment przyjęto wartość 0,673 mm (tj. średnia średnica ziaren podsadzki). Wówczas spadek rozwartości skały nasyconej płynem szczelinującym o 0,168 mm stanowi 25\% jej pierwotnej rozwartości. Badana skała charakteryzuje się bardzo dobrymi właściwościami umożliwiającymi podsadzenie wytworzonej szczeliny podsadzką ceramiczną ISP 20/40 dla zapewnienia przepływu przez nią węglowodorów do odwiertu.

Artykuł powstał na podstawie pracy statutowej pt.: Badania zjawiska wgniatania ziaren proppantu $w$ skate piaskowcowa typu zamkniętego - praca INiG - PIB na zlecenie MNiSW; nr zlecenia: 0041/KS/2019, nr archiwalny: DK-4100-0041/2019.

\section{Literatura}

Akrad O., Miskimins J., Prasad M., 2011. The Effects of Fracturing Fluids Rock Mechanical Properties and Proppant Embedment. Society of Petroleum Engineers. DOI: 10.2118/146658-MS.

Alramahi B., Sundberg M.I., 2012. Proppant Embedment and Conductivity of Hydraulic Fractures in Shales. ARMA-2012-291.

Czupski M., Kasza P., Wilk K., 2013. Płyny do szczelinowania złóż niekonwencjonalnych. Nafta-Gaz, 1: 42-50.

Dyrka I., Kiersnowski H., Wójcicki A. Możliwość występowania w Polsce złóż typu BCGS (Basin Centered Gas System). <https:// www.pgi.gov.pl/psg-1/psg-2/informacja-i-szkolenia/wiadomosci-surowcowe/10872-mozliwosc-wystepowania-w-polsce-zloz-typubcgs-basin-centered-gas-system.html> (dostęp: listopad 2019).

Economides M.J., Nolte K.G., 1989. Reservoir Stimulation. Second edition. Gulf Publishing Co., Houston.

Ghassemi A., Suarez-Rivera R., 2012a. Sustaining Fracture Area and Conductivity of Gas Shale Reservoirs for Enhancing Long-Term Production and Recovery. RPSEA. Projekt nr 08122-48.

Ghassemi A., Suarez-Rivera R., 2012b. Sustaining Fracture Area and Conductivity of Gas Shale Reservoirs for Enhancing Long-Term Production and Recovery. Appendix 5 - Proppant Embedment Standard Testing Procedure. RPSEA. Projekt nr 08122-48.

Gidley J.L., Holditch S.A., Nierode D.A., Veatch R.V., 1989. Recent Advances in Hydraulic Fracturing. Society of Petroleum Engineers. Monograph Series, 12.

Guo J., Liu Y., 2012. Modeling of Proppant Embedment: Elastic Deformation and Creep Deformation. Society of Petroleum Engineers. DOI: 10.2118/157449-MS.

Kasza P., 2011. Zabiegi stymulacji wydobycia w niekonwencjonalnych złożach węglowodorów. Nafta-Gaz, 10: 697-701.

Kasza P., 2019. Zabiegi hydraulicznego szczelinowania złóż niekonwencjonalnych i metody ich analizy. Prace Naukowe Instytutu Nafty i Gazu - Państwowego Instytutu Badawczego, 226: 1-147. DOI: $10.18668 / \mathrm{PN} 2019.226$.

Masłowski M., 2014. Materiały podsadzkowe do zabiegów hydraulicznego szczelinowania złóż niekonwencjonalnych. Nafta-Gaz, 2: 75-86.

Masłowski M., 2015. Badania zjawiska wciskania ziaren materiału podsadzkowego w ściany szczeliny po zabiegu hydraulicznego szczelinowania złóż niekonwencjonalnych. Nafta-Gaz, 7: 461-471.

Masłowski M., Biały E., 2016. Badania zjawiska embedment w zabiegach stymulacyjnych. Nafta-Gaz, 12: 1101-1106. DOI: 10.18668/ NG.2016.12.13.

Masłowski M., Kasza P., Czupski M., 2016. Badania podatności skały złożowej typu tight gas na zjawisko embedment ograniczające efektywność zabiegu hydraulicznego szczelinowania. Nafta-Gaz, 10: 822-832. DOI: 10.18668/NG.2016.10.07.
Masłowski M., Kasza P., Czupski M., Wilk K., 2018a. Sposób wyznaczania zmniejszenia rozwartości podsadzonej szczeliny. Urząd Patentowy RP. Patent nr 228609.

Masłowski M., Kasza P., Czupski M., Wilk K., Moska R., 2019. Studies of Fracture Damage Caused by the Proppant Embedment Phenomenon in Shale Rock. Applied Sciences-Basel, 9(11): 1-14. DOI: $10.3390 /$ app9112190.

Masłowski M., Kasza P., Wilk K., 2018b. Studies on the effect of the proppant embedment phenomenon on the effective packed fracture in shale rock. Acta Geodynamica et Geomaterialia, 15, 2(190): 105-115. DOI: 10.13168/AGG.2018.0012.

Paktinat J., Pinkhouse J.A., Johanson N., Williams C., Lash G.G., Penny G.S., Goff D.A., 2006. Case study: optimizing hydraulic fracturing performance in northeastern United States fractured shale formation. Society of Petroleum Engineers. DOI: 10.2118/104306-MS.

Papiernik B., Górecki W., Pasternacki A., 2010. Wstępne wyniki modelowań przestrzennych (3D) parametrów petrofizycznych skał podczas poszukiwań stref występowania gazu zamkniętego w polskim basenie czerwonego spągowca. Przegląd Geologiczny, 58(4): 352-364.

Poprawa P., Kiersnowski H., 2010. Potencjał dla poszukiwań gazu ziemnego zamkniętego w utworach czerwonego spągowca Polski na tle poszukiwań w europejskim basenie permskim. Referat wygłoszony na konferencji Niekonwencjonalne złoża gazu ziemnego w Polsce - gaz w tupkach (shale gas) i gaz zamknięty (tight gas), Warszawa.

Reinicke A., Legarth B., Zimmermann G., Huenges E., Dresenn G., 2006. Hydraulic Fracturing and Formation Damage in a Sedimentary Geothermal Reservoir. ENGINE - Enhanced Geothermal Innovative Network for Europe Workshop 3, Stimulation of reservoir and microseismicity. Kartause Ittingen, Zürich, Switzerland.

Reinicke A., Rybacki E., Stanchits S., Huenges E., Dresen G., 2010. Hydraulic fracturing stimulation techniques and formation damage mechanisms - Implications from laboratory testing of tight sandstone - proppant systems. Chemie dee Erde, 70: 107-117. DOI: 10.1016/j.chemer.2010.05.016.

Terracina J.M., Turner J.M., Collins D.H., Spillars S.E., 2010. Proppant Selection and Its Effect on the Results of Fracturing Treatments Performed in Shale Formations. Society of Petroleum Engineers. DOI: $10.2118 / 135502-\mathrm{MS}$.

Wójcicki A., Kiersnowski H., Dyrka I., Adamczak-Biały T., Becker A., Głuszyński A., Janas M., Kozłowska A., Krzemiński L., Kuberska M., Pacześna J., Podhalańska T., Roman M., Skowroński L., Waksmundzka M.I., 2014. Prognostyczne zasoby gazu ziemnego w wybranych zwięzłych skałach zbiornikowych Polski. Państwowy Instytut Geologiczny - Państwowy Instytut Badawczy, Warszawa: 1-65.

Zhang F., Zhu H., Zhou H., Guo J., Bo H., 2017. Discrete-ElementMethod/Computational-Fluid-Dynamics Coupling Simulation of Proppant Embedment and Fracture Conductivity After Hydraulic Fracturing. Society of Petroleum Engineers. DOI: 10.2118/185172-PA.

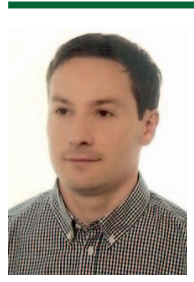

Mgr inż. Mateusz MASŁOWSKI

Asystent w Zakładzie Stymulacji Wydobycia Węglowodorów

Instytut Nafty i Gazu - Państwowy Instytut Badawczy ul. Lubicz 25 A

31-503 Kraków

E-mail: mateusz.maslowski@inig.pl 